\title{
Phospho-p38 MAPK Expression in COPD Patients and Asthmatics and in Challenged Bronchial Epithelium
}

\author{
Davide Vallese $^{\mathrm{a}}$ Fabio L.M. Ricciardolo ${ }^{\mathrm{b}}$ Isabella Gnemmi ${ }^{\mathrm{a}} \quad$ Paolo Casolari ${ }^{\mathrm{c}}$ \\ Paola Brun $^{d}$ Valentina Sorbello ${ }^{b}$ Armando Capelli $^{a}$ Francesco Cappello $^{e, f}$ \\ Giorgio Narciso Cavallesco ${ }^{9}$ Alberto Papi ${ }^{c}$ Kian Fan Chung ${ }^{\text {h }}$ Bruno Balbi ${ }^{a}$ \\ Ian M. Adcock ${ }^{\mathrm{h}}$ Gaetano Caramoric Antonino Di Stefano ${ }^{\mathrm{a}}$ \\ a'Divisione di Pneumologia e Laboratorio di Citoimmunopatologia dell'Apparato Cardiorespiratorio, Fondazione \\ Salvatore Maugeri, IRCCS, Veruno, b Divisione di Pneumologia, Ospedale San Luigi, Università di Torino, Orbassano, \\ 'Centro Interdipartimentale per lo Studio delle Malattie Infiammatorie delle Vie Aeree e Patologie Fumo-Correlate, \\ Sezione di Medicina Interna e Cardiorespiratoria, Dipartimento di Scienze Mediche, and d Dipartimento di Medicina \\ Molecolare, Università di Padova, Padova, and 'Sezione di Anatomia Umana, Dipartimento di Biomedicina \\ Sperimentale e Neuroscienze Cliniche, Università di Palermo, and ${ }^{\mathrm{f} E u r o-M e d i t e r r a n e a n ~ I n s t i t u t e ~ o f ~ S c i e n c e ~ a n d ~}$ \\ Technology, Palermo, ${ }^{9}$ Section of General and Thoracic Surgery, Department of Morphology, Experimental

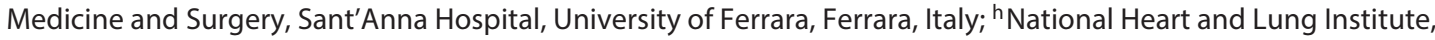 \\ Imperial College London, London, UK
}

\section{Key Words}

Mitogen-activated protein kinases $\cdot$ p65 - Pathology of chronic obstructive pulmonary disease $\cdot$ Chronic obstructive pulmonary disease phenotypes · Asthma phenotypes

\footnotetext{
Abstract

Background: The role of mitogen-activated protein kinases (MAPK) in regulating the inflammatory response in the airways of patients with chronic obstructive pulmonary disease (COPD) and asthmatic patients is unclear. Objectives: To investigate the expression of activated MAPK in lungs of COPD patients and in bronchial biopsies of asthmatic patients and to study MAPK expression in bronchial epithelial cells in response to oxidative and inflammatory stimuli. Methods: Immunohistochemical expression of phospho (p)-p38 MAPK, p-JNK1 and p-ERK1/2 was measured in bronchial mucosa in
}

patients with mild/moderate ( $\mathrm{n}=17)$, severe/very severe ( $n=16)$ stable COPD, control smokers $(n=16)$, control nonsmokers $(n=9)$, in mild asthma $(n=9)$ and in peripheral airways from COPD patients $(n=15)$ and control smokers $(n=$ 15). Interleukin (IL)-8 and MAPK mRNA was measured in stimulated $16 \mathrm{HBE}$ cells. Results: No significant differences in p-p38 MAPK, p-JNK or p-ERK1/2 expression were seen in bronchial biopsies and peripheral airways between COPD and control subjects. Asthmatics showed increased submucosal p-p38 MAPK expression compared to COPD patients $(p<0.003)$ and control non-smokers $(p<0.05)$. Hydrogen peroxide $\left(\mathrm{H}_{2} \mathrm{O}_{2}\right)$, cytomix (tumour necrosis factor- $\mathrm{a}+\mathrm{IL}-1 \beta+$ interferon- $\gamma$ ) and lipopolysaccharide (LPS) upregulated IL-8 mRNA at 1 or 2 h. p38 MAPKa mRNA was significantly increased after $\mathrm{H}_{2} \mathrm{O}_{2}$ and LPS treatment. JNK1 and ERK1 mRNA were unchanged after $\mathrm{H}_{2} \mathrm{O}_{2}$, cytomix or LPS treatments. Conclusion: $\mathrm{p}-\mathrm{p} 38$ MAPK expression is similar in stable COPD and control subjects but increased in the bronchi of mild

\section{KARGER 125}

(C) 2015 S. Karger AG, Basel

$0025-7931 / 15 / 0894-0329 \$ 39.50 / 0$

E-Mail karger@karger.com

www.karger.com/res
Antonino Di Stefano, $\mathrm{PhD}$

Fondazione Salvatore Maugeri, IRCCS, Divisione di Pneumologia e Laboratorio di Citoimmunopatologia dell'Apparato Cardiorespiratorio, Via per Revislate, 13 IT-28010 Veruno, NO (Italy)

E-Mail antonino.distefano@fsm.it 
asthmatics compared to stable COPD patients. p38 MAPK mRNA is increased after bronchial epithelial challenges in vitro. These data together suggest a potential role for this MAPK in Th2 inflammation and possibly during COPD exacerbations.

(c) 2015 S. Karger AG, Basel

\section{Introduction}

The mitogen-activated protein kinase (MAPK) family includes 3 distinct stress-activated protein kinase pathways: p38, c-Jun N-terminal kinase (JNK) and extracellular regulating kinase (ERK) [1]. The ERK pathway is predominantly activated by mitogenic and proliferative stimuli, whereas the JNK and p38 MAPK respond to environmental stresses [1]. A potential role of activated $\mathrm{p} 38$ MAPK has been reported for neutrophil and eosinophil lung cell migration, cytokine release from inflammatory cells and airway smooth muscle, release of matrix metalloproteinases, Th1 cell differentiation and interferon (IFN)- $\gamma$ production and induction of corticosteroid insensitivity [2]. MAPK and the pro-inflammatory transcription factor nuclear factor $-\kappa \mathrm{B}(\mathrm{NF}-\kappa \mathrm{B})$ are activated in airway epithelial cells and macrophages exposed to different stimuli such as lipopolysaccharide (LPS), cigarette smoke extracts and oxidants [3-8]. The production of mucin by airway epithelial cells is induced by oxidants and is accompanied by p38 MAPK phosphorylation and activation [6]. Cigarette smoke exposure of airway epithelial cells resulted in upregulation of interleukin (IL)-6 and IL- 8 mediated by p38 MAPK and NF- $\kappa B$ [9]. Rhinovirus exposure of human macrophages induces p38 MAPK activation and release of CCL1 (monocyte chemoattractant protein-1) [10]. Increased phospho (p)-p38 MAPK immunopositivity was reported in lung alveolar septa of chronic obstructive pulmonary disease (COPD) patients when compared to control smokers and nonsmokers [11], whilst p-p38 MAPK expression in lymphocytes within the submucosa of peripheral airways was similar in COPD patients, control smokers and nonsmokers [12]. In bronchial biopsies of asthmatics, epithelial staining for p-p38 MAPK and p-ERK1/2 was increased compared to healthy controls, while healthy subjects showed the highest p-JNK intensity [13]. MAPK expression and activation have not been studied to date in bronchial biopsies of COPD patients. Due to the role of p38 MAPK in inducing inflammation, p38 MAPK inhibitors have recently been studied, particularly in severe asthmatics and COPD patients [2]. The results obtained in these clinical trials are not particularly encouraging [14-16].

In COPD, the airflow limitation is usually progressive and associated with an abnormal inflammatory response of the lungs to noxious particles or gases $[17,18]$. Previous studies have emphasized the potential role of p38 MAPK in the pathogenesis of COPD and asthma [2]. However, the mechanisms of inducing p38 MAPK upregulation and its participation in the inflammatory state in the bronchi of COPD patients are not yet fully clarified.

The present study aimed: (1) to quantify by immunohistochemistry the activated MAPK expression in the bronchial biopsies and peripheral airways of patients with COPD and to compare these findings with control smokers, non-smoking subjects and a group of asthmatics, and (2) to investigate MAPK mRNA expression in vitro in bronchial epithelial cells in response to oxidative $\left(\mathrm{H}_{2} \mathrm{O}_{2}\right)$ and inflammatory (LPS, cytomix) stimuli which are implicated in COPD and asthma.

\section{Methods}

\section{Subjects}

All COPD and healthy control subjects who underwent bronchoscopy and bronchial biopsy collection were recruited from the Respiratory Medicine Unit of the Fondazione Salvatore Maugeri (Veruno, Italy). Asthmatics were recruited from the Division of Pneumology, Ospedale San Luigi, Orbassano, University of Torino, and the severity of asthma was classified according to the GINA and ATS criteria $[19,20]$. In COPD patients, the severity of the airflow obstruction was staged using current GOLD criteria (www. goldcopd.com). All former smokers had stopped smoking for at least 1 year. COPD and chronic bronchitis were defined, according to international guidelines, as follows: COPD, presence of a postbronchodilator forced expiratory volume in $1 \mathrm{~s}\left(\mathrm{FEV}_{1}\right) /$ forced vital capacity (FVC) ratio $<70 \%$; levels of shortness of breath, chronic cough, sputum and numbers of exacerbations per year were also taken into account as suggested by new GOLD criteria; chronic bronchitis, presence of cough and sputum production for at least 3 months in each of 2 consecutive years [18]. All COPD patients were stable with no previous exacerbation in the 6 months before bronchoscopy. None of the COPD patients was treated with theophylline, antibiotics, antioxidants, mucolytics and/or glucocorticoids in the month prior to the bronchial biopsy. The peripheral lung tissues were collected at the University Hospital of Ferrara, during lung resection for a solitary peripheral neoplasm, and all subjects were not under regular treatment with glucocorticoids and/or bronchodilators. Asthmatics were under therapy following GINA criteria [19]. The study conformed to the Declaration of Helsinki and was approved by the ethics committees of the Fondazione Salvatore Maugeri, Veruno (Novara), San Luigi Hospital, Orbassano (Torino), and the University Hospital of Ferrara, Italy; written informed consent was obtained from each participant, and bronchial biopsies were performed according to the guidelines of the local ethics committee. 
Table 1. Primary antibodies and immunohistochemical conditions used for identification of MAPK and inflammatory cells

\begin{tabular}{llllll}
\hline Primary antibody & Origin & ID & Secondary antibody & Dilution & Positive control \\
\hline p-p38 & Santa Cruz & SC-17852-R & Rabbit & $1: 150$ & Nasal polyp, human tonsil \\
p-JNK1 & Abcam & Ab-18680 & Rabbit & $1: 150$ & Nasal polyp, human tonsil \\
p-ERK1/2 & Epitomics & $1481-1$ & Rabbit & $1: 100$ & Nasal polyp, human tonsil \\
CD4 & Dako & M716 & Mouse & $1: 100$ & Nasal polyp, human tonsil \\
CD8 & Dako & M7103 & Mouse & $1: 200$ & Nasal polyp, human tonsil \\
CD68 & Dako & M814 & Mouse & $1: 200$ & Nasal polyp, human tonsil \\
Neutrophil elastase & Dako & M752 & Mouse & $1: 100$ & Nasal polyp, human tonsil \\
\hline
\end{tabular}

\section{Lung Function Tests and Volumes}

Pulmonary function tests were performed as previously described [21] according to guideline recommendations [22]. Pulmonary function tests included measurements of $\mathrm{FEV}_{1}$ and $\mathrm{FEV}_{1} /$ FVC under baseline conditions in all the subjects examined (6200 Autobox Pulmonary Function Laboratory; Sensormedics Corp., Yorba Linda, Calif., USA). In order to assess the reversibility of airflow obstruction and postbronchodilator functional values, the $\mathrm{FEV}_{1}$ and $\mathrm{FEV}_{1} / \mathrm{FVC}$ percent measurements in the groups of subjects with $\mathrm{FEV}_{1} / \mathrm{FVC} \leq 70 \%$ before bronchodilator use was repeated $20 \mathrm{~min}$ after the inhalation of $0.4 \mathrm{mg}$ of salbutamol.

\section{Fibre-Optic Bronchoscopy, Collection and Processing of \\ Bronchial Biopsies}

Subjects were at the bronchoscopy suite at 8.30 a.m. after having fasted from midnight and were pretreated with atropine (0.6 $\mathrm{mg}$ i.v.) and midazolam (5-10 $\mathrm{mg}$ i.v.). Oxygen ( $3 \mathrm{l} / \mathrm{min}$ ) was administered via nasal prongs throughout the procedure, and oxygen saturation was monitored with a digital oximeter. Using local anaesthesia with lidocaine (4\%) to the upper airways and larynx, a fibre-optic bronchoscope (Olympus BF10 Key-Med, Southend, UK) was passed through the nasal passages into the trachea. Further lidocaine (2\%) was sprayed into the lower airways, and 4 bronchial biopsy specimens were taken from segmental and subsegmental airways of the right lower and upper lobes using size 19 cupped forceps. Bronchial biopsies for immunohistochemistry were gently extracted from the forceps and processed for light microscopy as previously described [21]. At least 2 samples were embedded in Tissue Tek II OCT (Miles Scientific, Naperville, Ill., USA), frozen within $15 \mathrm{~min}$ in isopentane precooled in liquid nitrogen and stored at $-80^{\circ} \mathrm{C}$. The best frozen sample was then oriented, and 6- $\mu \mathrm{m}$-thick cryostat sections were cut for immunohistochemical light microscopy analysis and processed as described below.

\section{Collection and Processing of the Peripheral Lung Tissue}

Thirty subjects undergoing lung resection surgery for a solitary peripheral neoplasm were recruited. Fifteen were smokers with normal lung function, and 15 subjects were smokers with COPD (table 3). All former smokers had stopped smoking for more than 1 year. No subject underwent pre-operative chemotherapy and/or radiotherapy and had been treated with bronchodilators, theophylline, antibiotics, antioxidants and/or glucocorticoids in the month prior to surgery. Lung tissue processing was performed as previously described $[23,24]$. Two to 4 randomly selected tissue blocks were taken from the subpleural parenchyma of the lobe obtained at surgery, avoiding areas grossly invaded by tumour. Samples were fixed in $4 \%$ formaldehyde in phosphate-buffered saline (PBS) at pH 7.2 and, after dehydration, embedded in paraffin wax. Serial sections $4 \mu \mathrm{m}$ thick were first cut and stained with haematoxylin-eosin in order to visualize the morphology and to exclude the presence of microscopically evident tumour infiltration. Tissue specimens were then cut for immunohistochemical analysis and were placed on charged slides as previously reported [24].

Immunohistochemistry on OCT-Embedded Bronchial Biopsies

One cryostat section from each biopsy was stained applying immunohistochemical methods with a panel of antibodies specific for inflammatory cells (CD4+, CD8+, CD68+, neutrophil elastase+) or p-MAPK (table 1). Briefly, after blocking non-specific binding sites with serum derived from the same animal species as the secondary antibody, primary antibody was applied at optimal dilutions in Tris-buffered saline $(0.15 \mathrm{M}$ saline containing $0.05 \mathrm{M}$ Tris-hydrochloric acid at $\mathrm{pH}$ 7.6) and incubated for $1 \mathrm{~h}$ at room temperature in a humid chamber. Antibody binding was demonstrated with secondary anti-mouse (Vector, BA 2000) or anti-rabbit (Vector, BA 1000) antibodies followed by ABC kit AP AK5000 Vectastain and fast red substrate (red colour) or ABC kit HRP Elite, PK6100, Vectastain and diaminobenzidine substrate (brown colour). Human tonsils or nasal polyps were used as positive controls. For the negative control, normal mouse or rabbit non-specific immunoglobulins (Santa Cruz Biotechnology, Santa Cruz, Calif., USA) were used at the same protein concentration as the primary antibody.

\section{Immunohistochemistry in Human Peripheral Lung Tissue}

Immunostaining of paraffin-embedded peripheral lung tissue was performed as previously described [23]. After deparaffinization and rehydration to expose the immunoreactive epitopes, the sections to be stained, immersed in retrieval solution citrate, $\mathrm{pH} 6.0$, or EDTA, pH 8.0, were incubated in a microwave oven (model NN S200W; Panasonic, Milano, Italy) on high power for $40 \mathrm{~min}$. Endogenous peroxidase activity was blocked by incubating slides in $3 \%$ $\mathrm{H}_{2} \mathrm{O}_{2}$ in PBS followed by washing in PBS. Cell membranes were permeabilized adding $0.1 \%$ saponin to the PBS. Non-specific labelling was blocked by coating with blocking serum (5\% normal goat serum) for $20 \mathrm{~min}$ at room temperature. After washing in PBS the sections were treated with the following primary antibodies: rabbit monoclonal p-p38 MAPK (p-Thr180/p-Tyr182; code 1229-1) and rabbit p-ERK1/p-ERK2 (p-Thr202/p-Tyr204; code 1229-1), both 
obtained from Epitomics, and mouse monoclonal anti-p-SAPK/ JNK (Thr183/Tyr185; www.scbt.com; code sc6254) at the dilution of $1.25,1: 50$ and 1:300, respectively. Sometimes we have used different primary antibodies for the immunohistochemical and the Western blotting (see below) studies because the cell signalling technology does not provide the concentration of their primary antibody, and this does not allow the use of appropriate negative controls (non-specific IgG at the same concentration of the primary antibody) for immunohistochemical studies. For the negative control slides normal rabbit or mouse non-specific immunoglobulins (Santa Cruz Biotechnology) were used at the same protein concentration as the primary antibody. Control slides were included in each staining run using human normal tonsils (kindly provided by Prof. Stefano Pelucchi, ENT Section at the University of Ferrara, Italy) as a positive control for all the immunostaining performed. After repeated washing steps with PBS, the sections were subsequently incubated with goat anti-rabbit or horse anti-mouse biotinylated antibody (Vector ABC Kit, Vector Laboratories; www.vectorlabs.com) for $30 \mathrm{~min}$ at room temperature. After further washing, the sections were subsequently incubated with $\mathrm{ABC}$ reagent (Vector $\mathrm{ABC}$ kit, Vector Laboratories) for $30 \mathrm{~min}$ at room temperature. Slides were then incubated with chromogen-fast diaminobenzidine as chromogenic substance, after which they were counterstained in haematoxylin and mounted on permanent mounting medium.

\section{Scoring System for Immunohistochemistry in the Bronchial} Biopsies

Morphometric measurements were performed with a light microscope (Leitz Biomed, Leica, Cambridge, UK) connected to a video recorder linked to a computerized image system (Quantimet 500 Image Processing and Analysis System, Software Qwin V0200B, Leica). Light-microscopic analysis was performed at a magnification of $\times 630$.

The immunostaining for all antigens studied was scored (range: from 0 = absence of immunostaining to 3 = extensive intense immunostaining) in the intact (columnar and basal epithelial cells) bronchial epithelium, as previously described [21]. The final result was expressed as the average of all scored fields performed in each biopsy. A mean \pm SD of $0.700 \pm 0.260 \mathrm{~mm}$ of epithelium was analysed in COPD patients and control subjects. Immunostained cells in bronchial biopsy lamina propria were quantified $100 \mu \mathrm{m}$ beneath the epithelial basement membrane in several non-overlapping high-power fields until the whole specimen was examined. The final result, expressed as the number of positive cells per square millimetre, was calculated as the average of all the cellular counts performed in each biopsy.

\section{Scoring System for Immunohistochemistry in the Peripheral}

Lung Tissue

Staining analysis was performed as previously described [24]. Staining data were interpreted blinded with no prior knowledge of the clinicopathological parameters. A bronchiole was taken to be an airway with no cartilage and glands in its wall. To count the number of positive cells on the sections stained for p-p38 MAPK, p-JNK and p-ERK, the area of bronchiolar epithelium to be studied was selected randomly. Cells with nuclear immunostaining were counted on each of 10 consecutive, non-overlapping, high-power fields (about 300 cells) with 1 count on each of 3 , when available, bronchioles for each section stained. Results were expressed as percentages of total bronchiolar epithelial cells counted.
To quantify kinase expression in alveolar macrophages, at least 20 high-power fields of lung parenchyma were randomly selected for each section, and at least 100 macrophages inside alveoli were evaluated. Alveolar macrophages were defined as mononuclear cells with well-represented cytoplasm present in the alveolar spaces and not attached to the alveolar walls using a previously validated method [25]. Results were expressed as percentages of total alveolar macrophages counted.

\section{Western Blot Analysis for p-p38 MAPK, p-JNK and p-ERK in} the Peripheral Lung

Whole cell protein extraction from peripheral lung parenchyma, gel electrophoresis and nitrocellulose filter transfer were performed as previously described [21]. After blocking for $45 \mathrm{~min}$ at room temperature in Tris-buffered saline, $0.05 \%$ Tween-20 and $5 \%$ non-fat dry milk, filters were incubated with rabbit anti-pp38 MAPK (Cell Signalling, monoclonal antibody No. 9215) or rabbit anti-p-JNK1 (Abcam, Ab-18680) or rabbit anti-p-pERK1/2 (Epitomics, 1481-1) for $1 \mathrm{~h}$ at room temperature in Tris-buffered saline, $0.05 \%$ Tween-20 and 5\% non-fat dry milk at a dilution of $1: 500$ to $1: 1,000(0.1-0.2 \mathrm{mg} / \mathrm{ml})$. HeLa cells were used as positive controls. After washing, filters were incubated with goat antirabbit (Dako, UK) antibody conjugated to horseradish peroxidase at a dilution of 1:4,000. Visualization was performed using enhanced chemiluminescence as recommended by the manufacturer (Amersham Pharmacia Biotech). Anti-human actin antibody (Santa Cruz Biotechnology) was used as an internal control. Bands were quantified using densitometry with Grab-It and VisionWorks LS software (UVP, Cambridge, UK) and expressed as a ratio with the corresponding actin optical density value of the same line.

\section{Cell Culture and Treatments}

We used the SV40 large T antigen-transformed 16HBE cell line that retains the differentiated morphology and function of normal human bronchial epithelial cells [26]. For experiments 16HBE cells were passaged using Dulbecco's modified minimum essential medium (DMEM), supplemented with $10 \% \mathrm{v} / \mathrm{v}$ fetal bovine serum (FBS), $50 \mathrm{IU} / \mathrm{ml}$ penicillin, $50 \mu \mathrm{g} / \mathrm{ml}$ streptomycin, $1 \times$ non-essential amino acids, $1 \mathrm{~mm}$ sodium pyruvate and $2 \mathrm{mM}$ glutamine $\left(37^{\circ} \mathrm{C}, 5 \% \mathrm{CO}_{2}\right)$. When cells were at $60-70 \%$ confluence, the complete medium was replaced with DMEM without FBS for starvation time $(24 \mathrm{~h})$, followed by DMEM plus $1 \%$ FBS in the absence or presence of $\mathrm{H}_{2} \mathrm{O}_{2}(100 \mu \mathrm{M})$, cytomix (TNF- $\alpha 10 \mathrm{ng} / \mathrm{ml}+\mathrm{IL}-1 \beta$ $1 \mathrm{ng} / \mathrm{ml}+\mathrm{IFN}-\gamma 10 \mathrm{ng} / \mathrm{ml}$; R\&D System), LPS from Pseudomonas aeruginosa (Sigma, L9143; $10 \mu \mathrm{g} / \mathrm{ml}$ ), at 1, 2 and $4 \mathrm{~h}$. Passage numbers of cells used in this study ranged from 22 to 24 . All experiments were performed at least in quadruplicate for 4 independent experiments for each type of treatment $\left(\mathrm{H}_{2} \mathrm{O}_{2}\right.$, cytomix, LPS $)$ and each time of exposure $(1,2,4 \mathrm{~h})$.

\section{Extraction and Quantification of RNA and qRT-PCR from $16 \mathrm{HBE}$}

Total cellular RNA from exposed and non-exposed cultures was purified and isolated using an RNAspin Mini RNA Isolation kit (GE Healthcare) following the manufacturer's instructions. Total RNA was resuspended in $100 \mu \mathrm{l}$ nuclease-free water. RNA concentration was determined using a UV/visible spectrophotometer ( $\lambda$ 260/280 nm, Eppendorf BioPhotometer plus) and stored at $-80^{\circ} \mathrm{C}$. 
Table 2. Clinical characteristics of COPD, asthmatics and control subjects studied by bronchial biopsy analysis

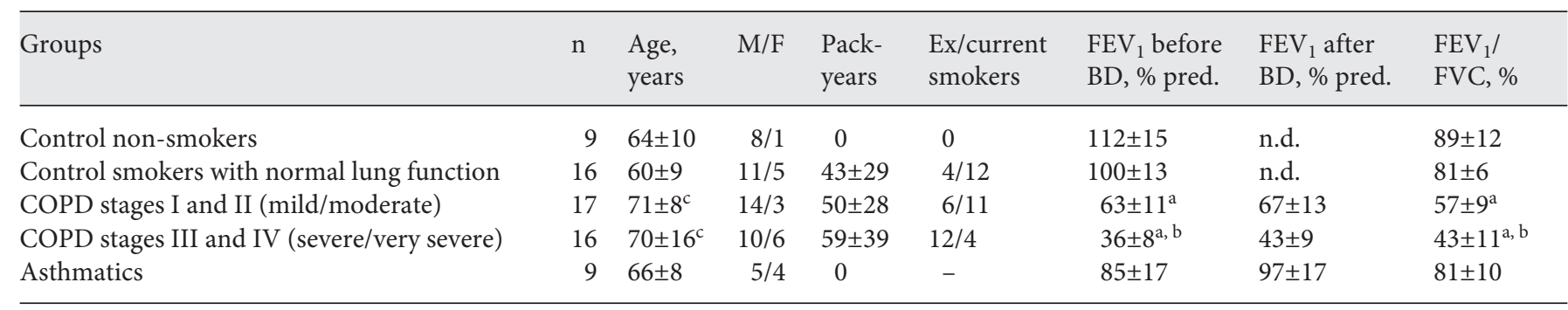

Patients were classified according to GOLD (http://www-goldcopd.com) levels of severity for COPD into mild (stage I), moderate (stage II), severe (stage III) and very severe (stage IV). Mild asthmatics were classified according to the GINA and ATS criteria. Data are means \pm SD. For COPD and asthmatic patients $\mathrm{FEV}_{1} / \mathrm{FVC}(\%)$ are postbronchodilator values. $\mathrm{M}=\mathrm{Male} ; \mathrm{F}=$ female; $\mathrm{BD}=$ bronchodilator; $\mathrm{n} . \mathrm{d} .=$ not determined. Statistics (ANOVA): ${ }^{a} p<0.0001$, significantly different from control smokers with normal lung function and control neversmokers; ${ }^{\mathrm{b}} \mathrm{p}<0.0001$, significantly different from mild/moderate COPD; ${ }^{\mathrm{c}} \mathrm{p}<0.05$, significantly different from control smokers with normal lung function.

The expression of genes of interest was measured using Syber green (Qiagen, UK) for qPCR in a Corbett Rotor Gene 6 (Corbett, Cambridge, UK) system. One-step real-time PCR was carried out by amplifying mRNA using the QuantiFast ${ }^{\mathrm{TM}}$ Syber green RTPCR kit (Qiagen, Italy) according to the manufacturer's instructions and the gene specific primers (Qiagen, Italy). We detected the expression of CXCL8 (IL-8; cat. QT00000322, Qiagen), p38a (cat. QT00079345), JNK1 (cat. QT00091056), ERK1 (cat. QT00065933) and NF- $\mathrm{B}$ p65 (cat. QT01007370) mRNA after each stimulation. We performed independent experiments and quantitative PCR measurements in quadruplicate for each type of treatment $\left(\mathrm{H}_{2} \mathrm{O}_{2}\right.$, cytomix, LPS $)$ and each $16 \mathrm{HBE}$ time of exposure $(1,2,4 \mathrm{~h})$. A single qPCR determination was performed for each type of treatment and time of exposure. Briefly, the PCR reaction mix, prepared in a total volume of $25 \mu \mathrm{l}$, was run on the Rotor Gene Q (Qiagen, Italy), and the following PCR run protocol was used: $55^{\circ} \mathrm{C}$ for $10 \mathrm{~min}$ (reverse transcription); $95^{\circ} \mathrm{C}$ for $5 \mathrm{~min}$ (PCR initial activation step); 40 amplification cycles of $95^{\circ} \mathrm{C}$ for $5 \mathrm{~s}$ (denaturation) and $60^{\circ} \mathrm{C}$ for $10 \mathrm{~s}$ (combined annealing/extension), followed by melting curve analysis to ensure the specificity of PCR amplification. Glyceraldehyde-3-phosphate dehydrogenase (GAPDH; QT01192646, Qiagen) was used as the reference gene for every target gene per sample, and the data were normalized against the respective GAPDH signalling. Cycle threshold values were determined using the Rotor Gene Q software (RotorGene Q Series Software 2.0.2). The expression levels of all genes studied were normalized to GAPDH levels in each sample to determine the expression between treated and non-treated cells using the $2^{-\Delta C_{t}}$ method [27].

\section{Statistical Analysis}

Group data were expressed as mean (with standard deviation) for functional data and median (with range) or interquartile range for morphological data. Differences between groups were analysed using analysis of variance (ANOVA) for functional data. The ANOVA test was followed by the unpaired t test for comparison between groups. The Kruskal-Wallis test applied for morphological data was followed by the Mann-Whitney U test for comparison between groups. In vitro data were expressed as means \pm standard deviation and analysed by the t test. Correlation coefficients were calculated using the Spearman rank method. Probability values of $\mathrm{p}<0.05$ were considered significant. Data analysis was performed using the Stat View SE Graphics program (Abacus Concepts Inc., Berkeley, Calif., USA).

\section{Results}

\section{Clinical Characteristics of Subjects Studied by Immunohistochemistry}

We obtained and studied bronchial biopsies from 58 subjects: 33 with stable COPD, 16 were current or exsmokers with normal lung function, and 9 were nonsmokers with normal lung function (table 2). COPD patients were divided into 2 groups: mild/moderate (GOLD stage I-II, $\mathrm{n}=17$ ) and severe/very severe (GOLD stage III-IV, $\mathrm{n}=16$; www.goldcopd.com). Subjects in all 4 groups were age-matched. The smoking history was similar in the 3 smoking groups. Values of $\mathrm{FEV}_{1}$ (\% predicted) and $\mathrm{FEV}_{1} / \mathrm{FVC}(\%)$ were significantly different in the groups with mild/moderate and severe/very severe COPD compared to both control groups (healthy smokers and healthy non-smokers). Severe/very severe COPD patients also differed significantly from mild/moderate COPD patients (for overall groups, ANOVA test: $\mathrm{p}<0.0001$ for $\mathrm{FEV}_{1} \%$ predicted and $\mathrm{FEV}_{1} / \mathrm{FVC} \%$ values). Thirty-six percent $(n=12)$ of the total COPD patients and $25 \%(n=$ 4) of healthy smokers with normal lung function also had symptoms of chronic bronchitis. There was no significant difference when COPD patients and healthy smokers were compared for the presence of chronic bronchitis. For comparative purposes related to the expression of $\mathrm{p}$ - 
Table 3. Characteristics of subjects for the immunohistochemistry and Western blotting studies on the peripheral lung tissue

\begin{tabular}{lllllllll}
\hline Subjects & $\mathrm{n}$ & Age, years & $\mathrm{M} / \mathrm{F}$ & $\begin{array}{l}\text { Ex/current } \\
\text { smokers }\end{array}$ & Pack-years & $\begin{array}{l}\text { Chronic } \\
\text { bronchitis (yes/no) }\end{array}$ & $\mathrm{FEV}_{1}, \%$ pred. & $\mathrm{FEV} / \mathrm{FVC}, \%$ \\
\hline Control smokers & 15 & $66 \pm 7$ & $12 / 3$ & $8 / 7$ & $40 \pm 34$ & $7 / 8$ & $100.3 \pm 15.6$ & $77 \pm 3.7$ \\
COPD patients & 15 & $69 \pm 7$ & $13 / 2$ & $8 / 7$ & $42 \pm 22$ & $7 / 8$ & $72.4 \pm 20^{*}$ & $58 \pm 9.7^{*}$ \\
\hline
\end{tabular}

Data are expressed as means $\pm \mathrm{SD} . \mathrm{M}=$ Male; $\mathrm{F}=$ female. For COPD patients and smokers with normal lung function, $\mathrm{FEV} \mathrm{V}_{1}$ and $\mathrm{FEV}_{1} / \mathrm{FVC}$ are postbronchodilator values. Statistics (ANOVA): ${ }^{*} \mathrm{p}<0.001$, significantly different from control smokers with normal lung function.

Table 4. Immunohistochemical quantification of inflammatory cells and MAPK related to inflammatory response in bronchial mucosa

\begin{tabular}{|c|c|c|c|c|c|}
\hline & $\begin{array}{l}\text { Control } \\
\text { non-smokers }\end{array}$ & Control smokers & $\begin{array}{l}\text { Mild/moderate } \\
\text { COPD }\end{array}$ & $\begin{array}{l}\text { Severe/very } \\
\text { severe COPD }\end{array}$ & $\begin{array}{l}\text { Kruskal-Wallis } \\
\text { p value }\end{array}$ \\
\hline \multicolumn{6}{|l|}{ Epithelium (score 0-3) } \\
\hline p-p38 & $0.75(0.25-1)$ & $0.75(0.25-1.25)$ & $0.5(0.25-1.25)$ & $0.5(0.25-1.5)$ & 0.618 \\
\hline $\mathrm{p}-\mathrm{JNK} 1$ & $0.12(0-0.25)$ & $0.1(0-1)$ & $0.12(0-1)$ & $0.25(0-1)$ & 0.521 \\
\hline $\mathrm{p}$-ERK $1 / 2$ & $0(0-0)$ & $0(0-0)$ & $0(0-0)$ & $0(0-0)$ & n.a. \\
\hline \multicolumn{6}{|l|}{ Submucosa, cells $/ \mathrm{mm}^{2}$} \\
\hline p-JNK1 & $5(0-20)$ & $7(0-45)$ & $17(0-64)$ & $11(3-51)$ & 0.262 \\
\hline $\mathrm{p}$-ERK1/2 & $0(0-6)$ & $0(0-21)$ & $0(0-13)$ & $0(0-2)$ & 0.212 \\
\hline $\mathrm{CD} 4$ & $164(101-212)$ & $246(37-500)$ & $258(107-731)$ & $252(66-470)$ & 0.206 \\
\hline CD8 & $147(76-301)$ & $179(86-657)$ & $195(86-523)$ & $244(111-355)^{\mathrm{a}}$ & 0.365 \\
\hline CD68 & $284(128-516)$ & $275(97-904)$ & $367(158-759)$ & $340(204-1,054)$ & 0.671 \\
\hline Neutrophil elastase & $93(58-166)$ & $97(45-308)$ & $94(28-512)$ & $151(47-470)^{\mathrm{a}, \mathrm{b}}$ & 0.045 \\
\hline
\end{tabular}

n.a. = Not applicable. Data expressed as medians (ranges). Statistics: the Kruskal-Wallis test was used for multiple comparisons followed by the Mann-Whitney U test for comparison between groups; ${ }^{\mathrm{a}} \mathrm{p}<0.05$, significantly different from control non-smokers; ${ }^{\mathrm{b}} \mathrm{p}<$ 0.05 , significantly different from control smokers with normal lung function; the exact $\mathrm{p}$ values for comparison between groups are given in the Results section.

MAPK in the bronchi of COPD patients and asthmatics, we also studied bronchial biopsies from 9 stable agematched mildly asthmatic patients. Clinical characteristics of asthmatics are included in table 2. Asthmatics were using short-acting bronchodilators on demand. Two out of 9 asthmatics were using inhaled corticosteroids at low doses.

We studied peripheral lung specimens from 15 stable COPD patients and 15 control smokers with normal lung function matched for their age and smoking history (table 3).

\section{Measurement of Inflammatory Cells in the Bronchial Submucosal Biopsies of COPD Patients}

These data, obtained from stable COPD patients by immunohistochemistry, confirm previously reported higher numbers of neutrophils and CD8+ cells in severe/ very severe COPD (table 4) [28]. COPD patients with chronic bronchitis had a similar number of neutrophils when compared with COPD patients without chronic bronchitis $[21,28]$.

\section{p-MAPK Immunohistochemistry in Bronchial Biopsies and Peripheral Airways \\ Immunohistochemistry in the Bronchial and \\ Bronchiolar Epithelium and Alveolar Macrophages}

In COPD and control subjects the most frequently expressed activated MAPK in bronchial epithelium was p-p38 MAPK. p-JNK1 was occasionally expressed in bronchial epithelium whereas p-ERK1/2 was virtually absent. Scored values for p-p38 MAPK and p-JNK1 did not show any significant differences between groups (table 4). No significant differences were observed for p-p38 MAPK between asthmatics (median 0.75, range 0.25-1.5) and 

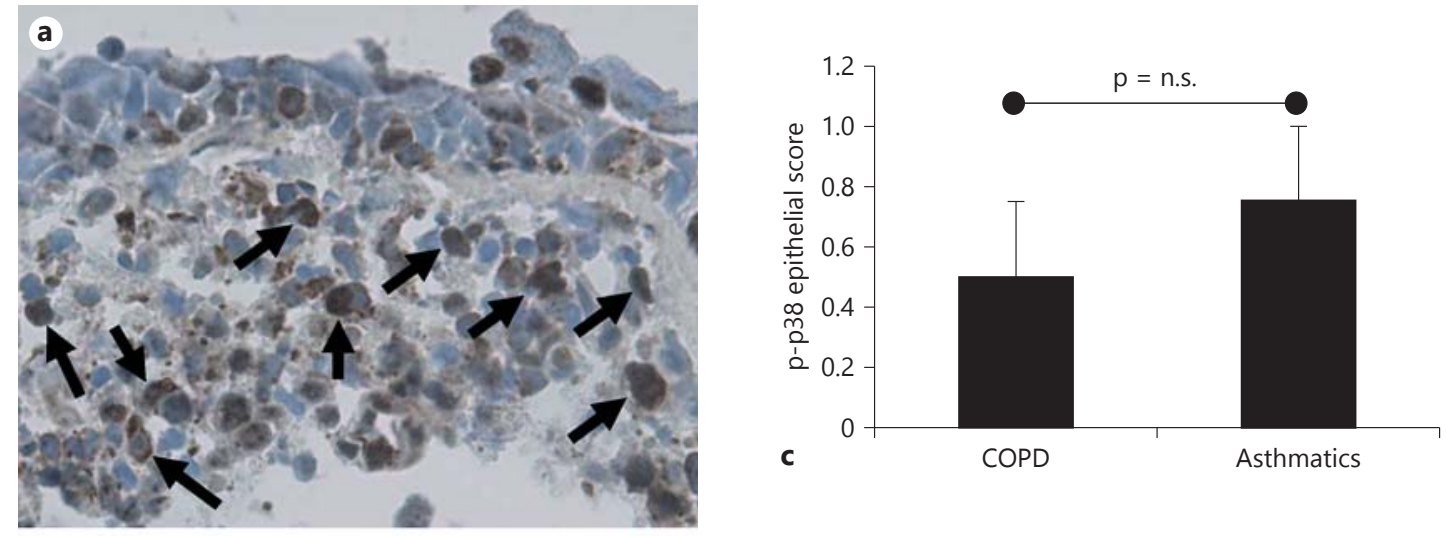

Fig. 1. Photomicrographs showing the bronchial mucosa from an asthmatic subject (a) and a patient with COPD (b) immunostained for identification of p-p38+ cells (arrows). Results are representative of those from 33 (mild/moderate and severe/very severe) COPD patients and 9 mild asthmatics. Column bar graphs indicate median (and interquartile range) values of p-p38 scored in the epithelium (c) and p-p38+ cells quantified in the submucosa (d) of all COPD patients $(n=33)$ and asthmatics $(n=9)$ studied. $p$ values are based on the Mann-Whitney test for comparison between groups. control non-smokers $(\mathrm{p}=0.958)$, severe/very severe COPD ( $\mathrm{p}=0.385)$, mild/moderate COPD $(\mathrm{p}=0.247)$ or all COPD patients ( $\mathrm{p}=0.249$; fig. 1$)$. Similarly, no significant differences were observed for $\mathrm{p}$-JNK1 between asthmatics (median 0.125, range $0-0.25$ ) and control non-smokers $(\mathrm{p}=0.957)$, severe/very severe COPD $(\mathrm{p}=$ $0.270)$, mild/moderate COPD ( $\mathrm{p}=0.345)$ or all COPD patients $(\mathrm{p}=0.256)$. No significant differences were observed for $\mathrm{p}$-ERK1/2 between asthmatics (median 0 , range $0-0)$ and control non-smokers ( $p>0.999)$, severe/ very severe COPD ( $\mathrm{p}>0.999)$, mild/moderate COPD ( $p>0.999)$ or all COPD patients either $(\mathrm{p}>0.999)$.

Immunohistochemistry in the Bronchial Submucosal Biopsies

In COPD and control subjects the most frequently expressed MAPK in bronchial submucosa was, as for epi- thelium, p-p38 MAPK. It was mainly expressed by mononuclear cells and occasionally by endothelial cells.p-JNK1 was poorly expressed in all groups studied, and p-ERK1/2 was only occasionally found. In COPD patients and control subjects no significant differences between groups were observed for all p-MAPK studied (table 4; fig. 2). Interestingly, asthmatics showed higher levels of p-p38 MAPK protein (median 125, range 54-387) when compared to control non-smokers $(\mathrm{p}=0.040)$, severe/very severe COPD $(\mathrm{p}=0.013)$, mild/moderate COPD ( $\mathrm{p}=$ 0.0018 ) or all COPD patients ( $\mathrm{p}=0.0016$; fig. 1$)$. No significant differences were observed for $\mathrm{p}$-JNK1/ $\mathrm{mm}^{2}$ counted in asthmatics (median 13, range 5-161) when compared to control non-smokers $(\mathrm{p}=0.112)$, severe/ very severe COPD $(\mathrm{p}=0.654)$, mild/moderate COPD $(\mathrm{p}=0.571)$ or all COPD patients $(\mathrm{p}=0.570)$. No significant differences were observed for $\mathrm{p}$-ERK $1 / 2 / \mathrm{mm}^{2}$ 


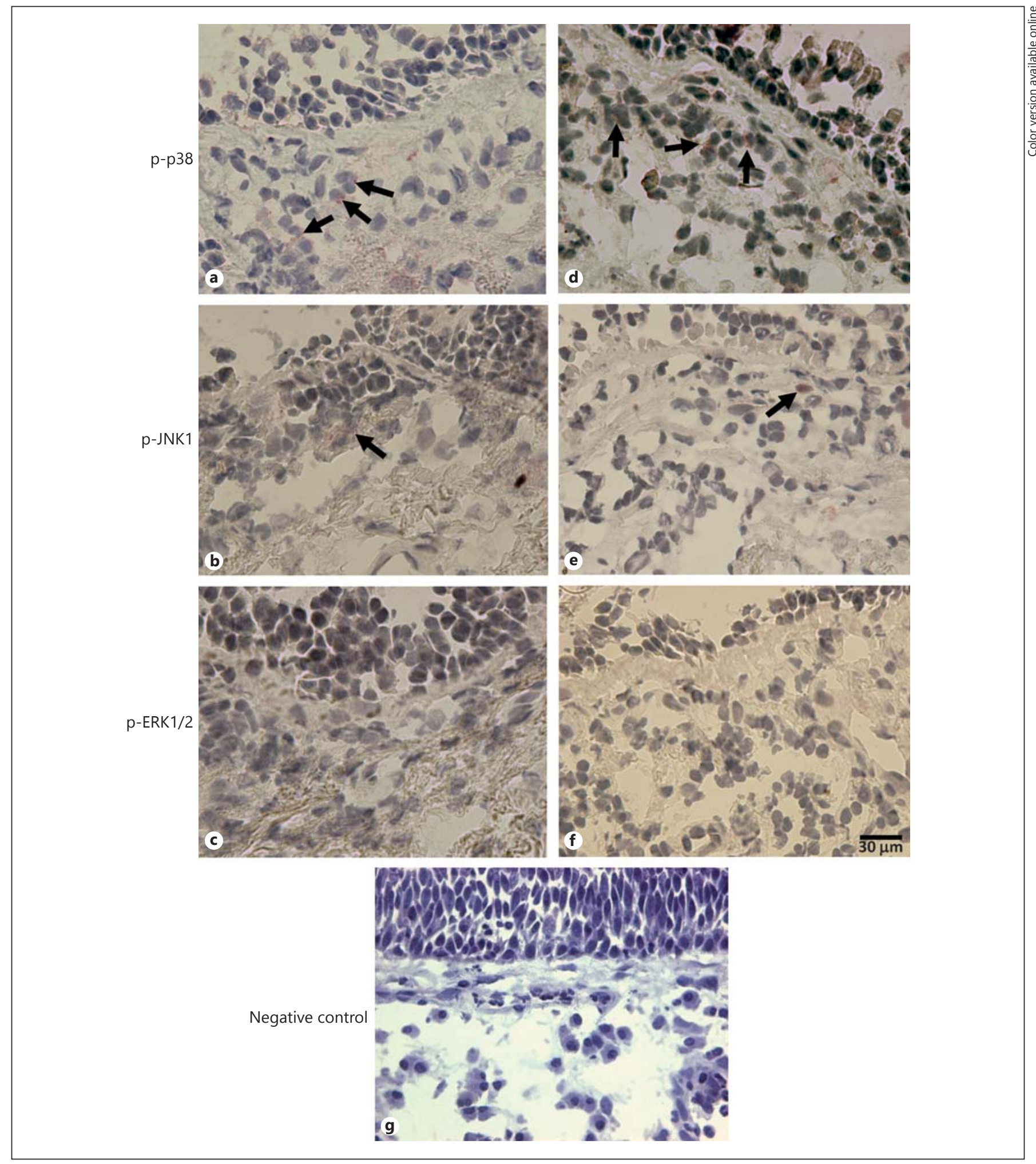

Fig. 2. Photomicrographs showing the bronchial mucosa from control non-smokers (a-c) and patients with mild/moderate COPD (d-f) immunostained (arrows) for identification of p-p38 $(\mathbf{a}, \mathbf{d}), \mathrm{p}-J \mathrm{NK} 1(\mathbf{b}, \mathbf{e})$ and p-ERK1/2 (c, f) in the bronchial epithe- lium and submucosa. Results are representative of those from 9 non-smokers and 33 COPD patients. g Negative control immunostaining, performed in a nasal polyp section, including an irrelevant rabbit primary antibody. 


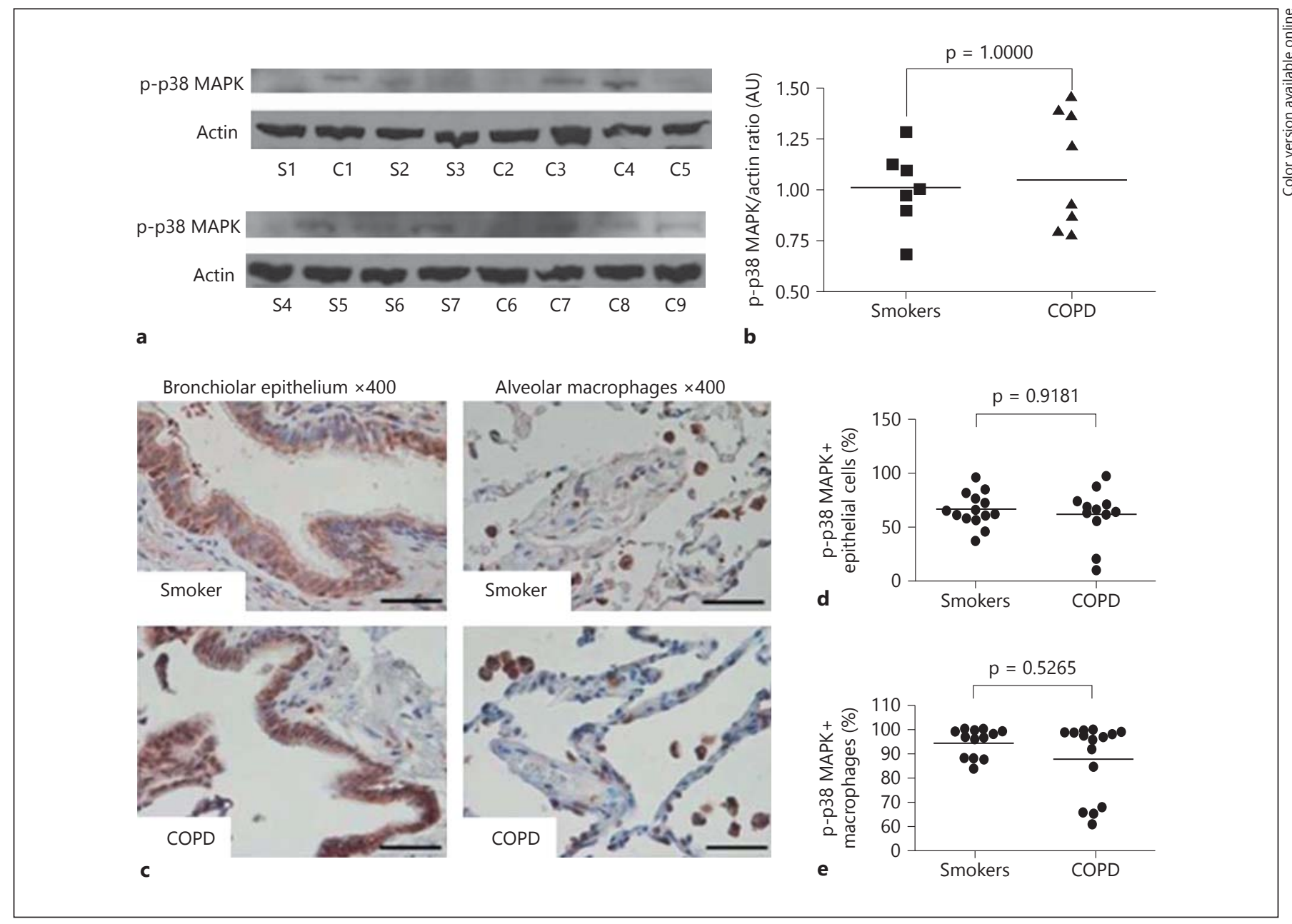

Fig. 3. a Western blot analysis of activated p-p38 MAPK in snapfrozen peripheral lung lysates of stable COPD $(n=9)$ and agematched control smokers with normal lung function $(n=7)$ with actin as the control for loading. b Graphical analysis of the densitometric ratio (arbitrary units, AU) of p-p38 MAPK/actin. c Im- munohistochemical images of p-p38 MAPK immunostaining in bronchiolar epithelial cells and alveolar macrophages representative of 15 COPD and 15 control smokers. Magnification $\times 400$. Bar $=50 \mu \mathrm{m}$. d, e Graphical presentation of the percentage of epithelial and macrophage staining. counted between asthmatics (median 5, range 0-17) and control non-smokers $(\mathrm{p}=0.216)$, mild/moderate COPD $(\mathrm{p}=0.608)$ or all COPD patients $(\mathrm{p}=0.156)$. A slight but significant increase was observed in asthmatics in comparison with severe/very severe COPD ( $\mathrm{p}=$ $0.034)$.

\section{Immunohistochemistry in the Peripheral Lung}

Tissue

In the peripheral airways no significant differences were observed for percentages of p-p38 MAPK immunostained bronchiolar epithelial cells between COPD (median 68, range 10-100) and control smokers (70, range $40-100 ; p=0.9181$ ). Percentages of $\mathrm{p}$-p38 MAPK+ alveolar macrophages in COPD (median 87, range 60100) versus control smokers (94, range 82-100; $\mathrm{p}=$ 0.5265 ) were not significantly different either (fig. 3 ).

No significant differences were observed for percentages of p-JNK immunostained bronchiolar epithelial cells between COPD (median 38, range 2-64) and control smokers (36, range 5-58; $\mathrm{p}=0.5439)$. Percentages of $\mathrm{p}$ $\mathrm{JNK}+$ alveolar macrophages in COPD (median 88 , range 60-100) versus control smokers (90, range 40-100; $\mathrm{p}=$ 0.3216 ) were not significantly different (fig. 4).

No significant differences were observed for percentages of p-ERK1/2-immunostained bronchiolar epithelial cells between COPD (median 40, range 0-90) and control smokers $(37$, range $0-70 ; \mathrm{p}=0.5495)$. Percent- 


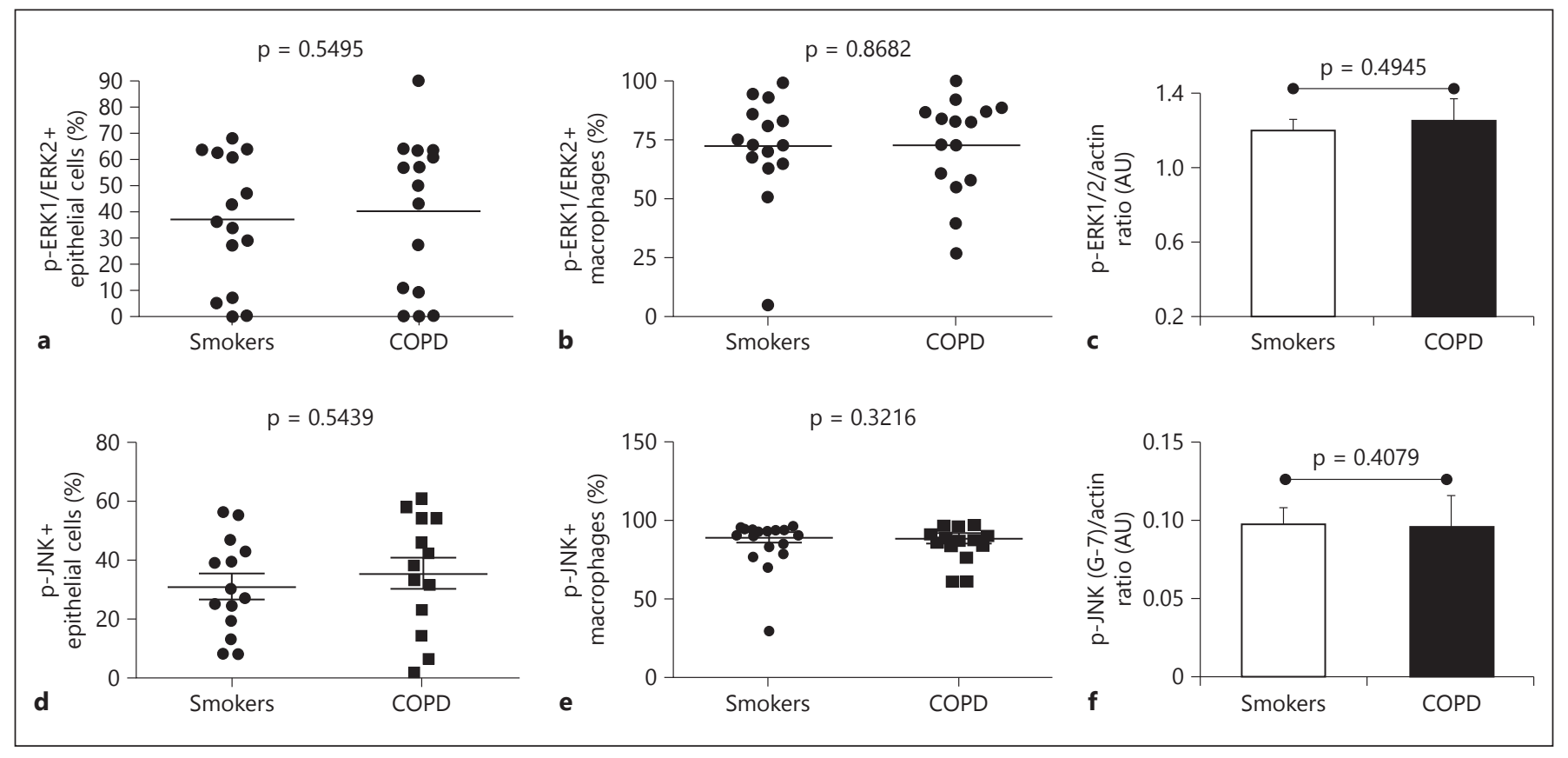

Fig. 4. Graphical presentation of the percentage of p-ERK1/2-immunostained bronchiolar epithelial cells (a), percentage of $\mathrm{p}$ ERK1/2-immunostained positive macrophages (b) and $\mathrm{p}$ ERK1/2/actin ratio from peripheral lung lysates (c), percentage of p-JNK-immunostained bronchiolar epithelial cells (d), percentage of p-JNK-immunostained positive macrophages (e) and p-

ages of p-ERK1/2+ alveolar macrophages in COPD (median 75, range 25-100) versus control smokers (72, range $8-100 ; p=0.8682$ ) were not significantly different either (fig. 4).

Western Blotting for p-p38 MAPK, p-JNK and p-ERK1/2 in Peripheral Lung Tissue

No significant differences were observed for the p-p38 MAPK/actin ratio between COPD (median 1.02, range $0.2-1.40$ ) and control smokers (1.0, range 0.65-1.30; $\mathrm{p}=$ 1.0000 ; fig. 3 ), the $\mathrm{p}-\mathrm{JNK} /$ actin ratio between COPD (median 0.10 , range $0.05-0.13)$ and control smokers $(0.10$, range $0.06-0.12 ; \mathrm{p}=0.4079$; fig. 4$)$ and the $\mathrm{p}-\mathrm{ERK} 1 / 2 /$ actin ratio between COPD (median 0.10 , range $0.05-$ 0.13 ) and control smokers $(0.10$, range $0.06-0.12 ; \mathrm{p}=$ 0.4079; fig. 4).

\section{Correlations between p-MAPK Cell Counts, Clinical \\ Parameters and Inflammatory Cells in the Bronchial \\ Biopsies}

In all smokers and in patients with COPD alone we did not observe any significant correlation between numbers of p-p38+, p-JNK1+ and p-ERK1/2+ cells per square mil-
JNK/actin ratio from peripheral lung lysates (f) in stable COPD and control smokers. AU = Arbitrary units. Data are representative of 15 stable COPD and 15 control smokers for immunohistochemical data and 9 stable COPD and 7 control smokers for Western blot analysis. The Mann-Whitney test was used for comparison between groups.

limetre and numbers of cigarettes smoked (pack-years), functional (spirometry values and clinical parameters) data or structural (inflammatory cells) data.

MAPK, NF- $\kappa B$ p65 and IL-8 mRNA Expression in $16 \mathrm{HBE}$ Cells Induced by Oxidative and Inflammatory Stimuli in vitro

Human bronchial epithelial (16HBE) cells were stimulated with $\mathrm{H}_{2} \mathrm{O}_{2}(100 \mu \mathrm{M}$ ), cytomix (TNF- $\alpha, 10 \mathrm{ng} / \mathrm{ml}$, IL- $1 \beta, 1 \mathrm{ng} / \mathrm{ml}$, and IFN- $\gamma, 10 \mathrm{ng} / \mathrm{ml})$ and LPS $(10 \mu \mathrm{g} /$ $\mathrm{ml}$ ), and the expression of IL-8 (fig. 5a), p38 MAPKa (fig. 5b), JNK1 (fig. 5c), ERK1 (fig. 5d) and NF- $\kappa B$ p65 subunit (fig. 5e) mRNA was quantified by qRT-PCR. IL-8 mRNA was significantly increased $2 \mathrm{~h}$ after $\mathrm{H}_{2} \mathrm{O}_{2}$ $(\mathrm{p}<0.0001), 1$ and $2 \mathrm{~h}$ after cytomix $(\mathrm{p}=0.001$ and $\mathrm{p}=$ 0.017 , respectively), and $2 \mathrm{~h}$ after LPS ( $\mathrm{p}=0.043$; fig. 5a). p38 MAPKa mRNA was significantly increased $2 \mathrm{~h}$ after $\mathrm{H}_{2} \mathrm{O}_{2}(\mathrm{p}=0.030)$ and $1 \mathrm{~h}$ after LPS $(\mathrm{p}=0.010)$ but it did not change after cytomix treatment (fig. 5b). JNK1 mRNA was not significantly changed by any of the treatments used (fig. 5c). ERK1 mRNA was not significantly increased after $\mathrm{H}_{2} \mathrm{O}_{2}$, cytomix or LPS treatments (fig. 5d). $\mathrm{NF}-\kappa \mathrm{B}$ p65 subunit mRNA was significantly increased 

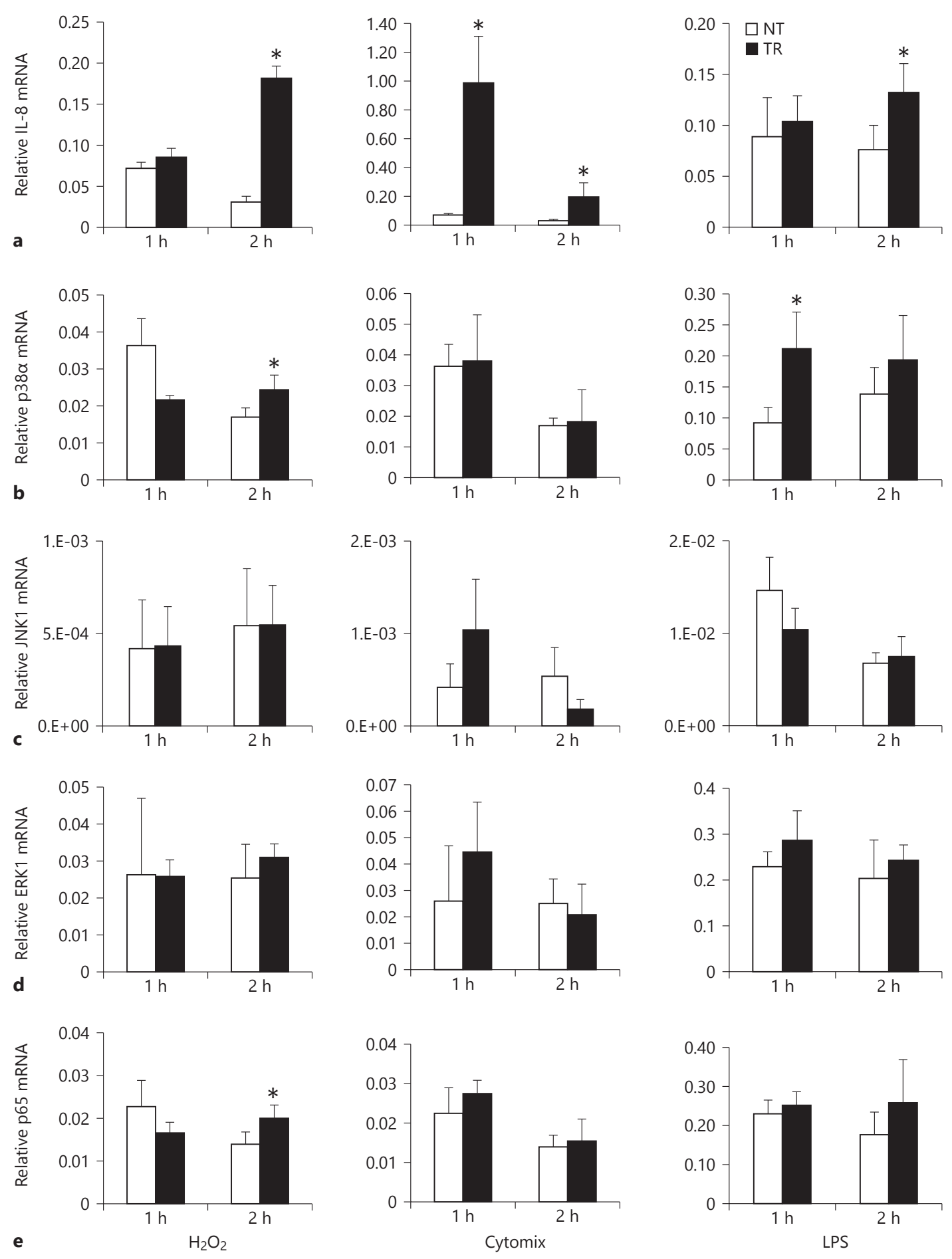

Fig. 5. In vitro expression of CXCL8 (IL-8; a), p38a (b), JNK1 (c), ERK1 (d) and NF- $\kappa B$ p65 subunit (e) mRNA in 16HBE cells treated with $\mathrm{H}_{2} \mathrm{O}_{2}(100 \mu \mathrm{M}$ ), cytomix (TNF- $\alpha, 10 \mathrm{ng} / \mathrm{ml}$, IL- $1 \beta, 1 \mathrm{ng} / \mathrm{ml}$, and IFN- $\gamma, 10 \mathrm{ng} / \mathrm{ml}$ ) and LPS from $P$. aeruginosa. All treatments upregulated IL- 8 mRNA expression 1 or $2 \mathrm{~h}$ after treatment (a). $\mathrm{H}_{2} \mathrm{O}_{2}$ stimulation upregulated p38 (b) and p65(e) mRNA $2 \mathrm{~h}$ after stimuli. LPS upregulated p-38 (b) mRNA 1 h after stimulus. All experiments were performed in quadruplicate. Data are expressed as means \pm standard deviation. Statistical analysis: $t$ test $\left({ }^{*} \mathrm{p}<0.05\right)$ for comparison between treated (TR) and non-treated (NT) cells. The exact $\mathrm{p}$ values for comparison between groups are given in the Results section. 
$2 \mathrm{~h}$ after $\mathrm{H}_{2} \mathrm{O}_{2}(\mathrm{p}=0.032)$ but it did not reach statistical significance $2 \mathrm{~h}$ after cytomix $(\mathrm{p}=0.086)$ and LPS $(\mathrm{p}=$ 0.093; fig. 5e).

\section{Discussion}

This study shows similar immune expression of p-p38 MAPK, p-JNK1 and p-ERK1/2 in the bronchial epithelium and submucosa of patients with mild/moderate and severe/very severe stable COPD when compared to control smokers and control non-smokers. Activated MAPK were also similarly expressed in the bronchiolar epithelium of stable COPD patients compared to control smokers with normal lung function. p-p38 MAPK immunopositivity in the bronchial submucosa of asthmatics was significantly increased when compared to stable COPD and control non-smokers. Interestingly, bronchial epithelial cells (16HBE) exposed in vitro to $\mathrm{H}_{2} \mathrm{O}_{2}$, cytomix and LPS showed increased levels of IL- 8 mRNA production which were accompanied by a parallel increase in p38 MAPK mRNA after $\mathrm{H}_{2} \mathrm{O}_{2}$ and LPS stimulation but not by a parallel increase in JNK1 and ERK1 mRNA. In patients with COPD, p-p38 MAPK immunopositivity was increased in the small airway epithelium [12] when compared to control non-smokers [12] and in alveolar septa [11] when compared to control smokers and nonsmokers [11]. p-p38 MAPK immunopositivity in lymphocytes populating the submucosa of peripheral airways of COPD patients was similar to that found in control smokers and non-smokers [12]. These last data are in part in agreement with our present observations of no changes of p-p38 MAPK immunopositivity in the bronchial biopsy submucosa of stable COPD patients compared to control smokers and non-smokers, peripheral airway bronchiolar epithelium of stable COPD patients compared to control smokers, and with our observation of the absence of significant changes in total p-p38 MAPK protein, measured by Western blot, using lung tissue, when comparing stable COPD patients and control smokers with normal lung function. In fact, p-p38 MAPK immunopositivity in our bronchial biopsy specimens was mainly observed in mononuclear cells and occasionally in endothelial cells, and in agreement with Gaffey et al. [12], the mononuclear cell component expressing p-p38 MAPK immunopositivity was similar in COPD patients and control subjects. At variance with previously reported data in peripheral airways [12] of COPD patients and in large airways from asthmatics [13], we did not find a significant increase in this MAPK in bronchial biopsy ep- ithelium in mild/moderate and severe/very severe COPD or in peripheral tissue. This may be due, in part, to the presence and influence of a different inflammatory state of the airways when bronchial biopsies of asthmatics are compared to COPD patients. It is conceivable that a Th2 prevalent inflammatory state, such as in asthma, could better activate MAPK, including p-p38 MAPK. To better understand possible differences between asthma and COPD, we directly compared immune expression of activated MAPK in bronchial biopsies from COPD and asthmatic subjects, matched for age and sex, and we observed a significant increase in p-p38 MAPK in bronchial submucosa of mild asthmatics compared to stable COPD patients. Asthmatics also differed significantly from control non-smokers, confirming, in part, previously reported data [13]. In our asthmatics we found the most significant difference in the submucosal area rather than in epithelium, as previously reported [13]. This indicates that increased p-p38 MAPK levels in our asthmatics are mainly due to an increased infiltration of inflammatory cells. A Th2-type prevalent inflammation, such as in asthma, may also favour the highest p-p38 MAPK expression observed in the bronchi of asthmatics [29].

Inhalation of LPS in human volunteers induced activation of bronchial epithelium by increased expression of p38 MAPK and IL-8 [30]. P. aeruginosa-challenged human bronchial epithelial cells showed increased phosphorylation of p38 MAPK and IL-8 gene expression which was reduced by the use of p38 inhibitors [31]. Flagellin from $P$. aeruginosa increased the expression of IL-8 in BEAS-2B cells compared to untreated cells, and addition of p38 MAPK inhibitors reduced IL-8 expression [32]. IL-8 mRNA and protein expression was also increased after LPS stimulation of bronchial epithelial cells [33]. Poly(I:C) costimulation further increased IL-8 production which was reversed by dexamethasone and a p38 MAPK inhibitor [33].

Hydrogen peroxide increased Wnt- 4 and IL- 8 gene expression in BEAS-2B cells [34]. Wnt-4-stimulated $16 \mathrm{HBE}$ cells significantly increased IL-8 secretion and p38 MAPK activation [35]. A lower efficacy of corticosteroids is reported in human bronchial epithelial cells in asthma and COPD after oxidative stress challenge $[2,36]$. In paediatric bronchial epithelial cells, Th2 cytokine challenge in the presence of rhinovirus-16 infection augmented IL-8 release [29]. Housedust mite-induced IL-8 release is blocked by an ERK inhibitor in human lung epithelial cells [37]. Our in vitro experiments show that $16 \mathrm{HBE}$ cells stimulated with $\mathrm{H}_{2} \mathrm{O}_{2}$, cytomix and LPS upregulated IL-8 mRNA expression, in agreement with previously report- 
ed observations [30-37]. This was associated with upregulation of p38a MAPK but not JNK1 and ERK1 mRNA after $\mathrm{H}_{2} \mathrm{O}_{2}$ and LPS exposure. Interestingly, $\mathrm{H}_{2} \mathrm{O}_{2}$ also increased NF- $\kappa B$ p 65 mRNA. These data suggest that in bronchial epithelial cells the p38 MAPK pathway may be more relevant after LPS and oxidative stimulation.

Our bronchial biopsy data, showing a significant increase in p-p38 MAPK immune positivity in mild asthmatics and its prevalence in stable COPD patients, taken together with our in vitro observations of increased p-p38 MAPKa mRNA after bronchial epithelial stimulation suggests that p-p38 MAPK activation may play a significant role in inducing bronchial inflammation in these diseases.

Recently, MacNee et al. [38] described an improvement in $\mathrm{FEV}_{1}$ after 6 weeks of p38 MAPK inhibitor treatment in moderate-to-severe COPD patients. In contrast, a larger study, performed in moderate-to-severe stable COPD patients, treated with the highly selective oral p38 MAPK inhibitor iosmapimod for 6 months, showed no significant changes in exercise tolerance or lung function [16]. This highlights the need to better define the clinical phenotype of patients in order to identify a likely 'responder' population of COPD patients $[14,15]$. Our present results may contribute to this scope since p-p38 MAPK was certainly the most expressed MAPK in our bronchial specimens from asthmatics and COPD patients, and specific oxidative and inflammatory challenges, performed in $16 \mathrm{HBE}$ cells, showed a significant in- crease in p-p38 MAPKa mRNA after challenges. Since mononuclear cell infiltration was reported as the prominent cellular type in bronchial biopsies of mild/moderate but not of severe/very severe COPD patients [39], and p-p38 MAPK expression, reported in the submucosa of bronchial biopsies, is mainly due to immunostained mononuclear cells, we can argue, therefore, that selected populations including mild-to-moderate COPD patients with a more inflamed airway (cut-off values for mononuclear cell inflammation should be defined) and COPD patients during an exacerbation or those who frequently exacerbate, or asthmatic patients, could better respond to p38 MAPK inhibitors. The potential for combination therapies, particularly in exacerbated diseased patients, together with a deeper analysis of molecular events and possible activation of redundant inflammatory pathways, developing after p38 MAPK blockade, needs to be further studied.

\section{Acknowledgements}

This work was supported by the Fondazione Salvatore Maugeri, IRCCS, Ricerca Corrente.

I.M.A. is supported by the MRC-ABPI COPD-MAP consortium (G1001367/1) and the Welcome Trust (093080/Z/10/Z). Research at the National Heart and Lung Institute is also supported by the NIHR Respiratory Disease Biomedical Research Unit at the Royal Brompton NHS Foundation Trust and Imperial College London.

\section{References}

1 Johnson GL, Lapadat R: Mitogen-activated protein kinase pathways mediated by ERK, JNK, and p38 protein kinases. Science 2002; 298:1911-1912.

- 2 Chung KF: p38 mitogen-activated protein kinase pathways in asthma and COPD. Chest 2011;139:1470-1479.

-3 Birrell MA, Wong S, Catley MC, Belvisi MG: Impact of tobacco-smoke on key signaling pathways in the innate immune response in lung macrophages. J Cell Physiol 2008;214: 27-37.

4 Bhavsar P, Hew M, Khorasani N, Torrego A, Barnes PJ, Adcock I, Chung KF: Relative corticosteroid insensitivity of alveolar macrophages in severe asthma compared with non-severe asthma. Thorax 2008;63:784790.

5 Woo CH, Lim JH, Kim JH: Lipopolysaccharide induces matrix metalloproteinase- 9 expression via a mitochondrial reactive oxygen species-p38 kinase-activator protein-1 path- way in Raw 264.7 cells. J Immunol 2004;173: 6973-6980.

6 Jang MK, Kim SH, Lee KY, Kim TB, Moon KA, Park CS, Bae YJ, Zhu Z, Moon HB, Cho YS: The tyrosine phosphatase, SHP-1, is involved in bronchial mucin production during oxidative stress. Biochem Biophys Res Commun 2010;393:137-143.

7 Heit B, Tavener S, Raharjo E, Kubes P: An intracellular signaling hierarchy determines direction of migration in opposing chemotactic gradients. J Cell Biol 2002;159:91-102.

8 Heuertz RM, Tricomi SM, Ezekiel UR, Webster RO: C-reactive protein inhibits chemotactic peptide-induced p 38 mitogen-activated protein kinase activity and human neutrophil movement. J Biol Chem 1999;274:1796817974.

-9 Beisswenger C, Platz J, Seifart C, Vogelmeier C, Bals R: Exposure of differentiated airway epithelial cells to volatile smoke in vitro. Respiration 2004;71:402-409.
10 Hall DJ, Bates ME, Guar L, Cronan M, Korpi $\mathrm{N}$, Bertics PJ: The role of $\mathrm{p} 38 \mathrm{MAPK}$ in rhinovirus-induced monocyte chemoattractant protein-1 production by monocytic-lineage cells. J Immunol 2005;174:8056-8063.

-11 Renda T, Baraldo S, Pelaia G, Bazzan E, Turato G, Papi A, Maestrelli P, Maselli R, Vatrella A, Fabbri LM, Zuin R, Marsico SA, Saetta M: Increased activation of $\mathrm{p} 38$ MAPK in COPD. Eur Respir J 2008;31:62-69.

12 Gaffey K, Reynolds S, Plumb J, Kaur M, Singh D: Increased phosphorylated p38 mitogenactivated protein kinase in COPD lungs. Eur Respir J 2013;42:28-41.

13 Liu W, Liang Q, Balzar S, Wenzel S, Gorska M, Alam R: Cell-specific activation profile of extracellular signal-regulated kinase $1 / 2$, Jun $\mathrm{N}$-terminal kinase, and p38 mitogen-activated protein kinases in asthmatic airways. J Allergy Clin Immunol 2008;121:893-902.

14 Singh D: p38 inhibition in COPD: cautious optimism. Thorax 2013;68:705-706. 
15 Calverley PM: New treatments for COPD: many miles still to go. Lancet Respir Med 2014;2:6-7.

16 Watz H, Barnacle H, Hartley BF, Chan R: Efficacy and safety of the p38 MAPK inhibitor losmapimod for patients with chronic obstructive pulmonary disease: a randomised, double-blind, placebo-controlled trial. Lancet Respir Med 2014;2:63-72.

17 Global Initiative for Chronic Obstructive Lung Disease (GOLD): global strategy for the diagnosis, management and prevention of chronic obstructive pulmonary disease. NHLBI/WHO workshop report. NIH Publication No 2701A. Last update 2011. http:// www.goldcopd.com/ (accessed May 28, 2014).

18 Vestbo J, Hurd SS, Agusti AG, Jones PW, Vogelmeier C, Anzueto A, et al: Global strategy for the diagnosis, management and prevention of chronic obstructive pulmonary disease, GOLD executive summary. Am J Respir Crit Care Med 2013;187:347-365.

19 Global Strategy for Asthma Management and Prevention: Global Initiative for Asthma (GINA). 2010. www.ginasthma.org.

20 Wenzel SE, Fahy JV, Irvin CG, Peters SP, Spector S, Szefler SJ: Proceedings of the ATS Workshop on Refractory Asthma: current understanding, recommendations and unanswered questions. Am J Respir Crit Care Med 2000;162:2341-2351.

21 Di Stefano A, Caramori G, Gnemmi I, Contoli M, Bristot L, Capelli A, Ricciardolo FL, Magno F, D’Anna SE, Zanini A, Carbone M, Sabatini F, Usai C, Brun P, Chung KF, Barnes PJ, Papi A, Adcock IM, Balbi B: Association of increased CCL5 and CXCL7 chemokine expression with neutrophil activation in severe stable COPD. Thorax 2009;64:968-975.

22 Quanjer PH, Tammeling GJ, Cotes JE, Pedersen OF, Peslin R, Yernault JC: Lung volumes and forced ventilatory flows. Report Working Party Standardization of Lung Function Tests, European Community for Steel and Coal. Official Statement of the European Respiratory Society. Eur Respir J Suppl 1993;16: 5-40.
23 Marwick JA, Caramori G, Stevenson CS, Casolari P, Jazrawi E, Barnes PJ, Ito K, Adcock IM, Kirkham P, Papi A: Inhibition of PI-3K $\delta$ restores steroid responsiveness in smokinginduced steroid insensitivity. Am J Respir Crit Care Med 2009;179:542-548.

24 Kirkham PA, Caramori G, Casolari P, Papi AA, Edwards M, Shamji B, Triantaphyllopoulos K, Hussain F, Pinart M, Khan Y, Heinemann L, Stevens L, Yeadon M, Barnes PJ, Chung KF, Adcock IM: Oxidative stress-induced antibodies to carbonyl-modified protein correlate with severity of chronic obstructive pulmonary disease. Am J Respir Crit Care Med 2011;184:796-802.

25 Maestrelli P, El Messlemani AH, De Fina O, Nowicki Y, Saetta M, Mapp C, Fabbri LM: Increased expression of heme oxygenase (HO)1 in alveolar spaces and HO-2 in alveolar walls of smokers. Am J Respir Crit Care Med 2001; 164:1508-1513.

26 Cozens AL, Yezzi MJ, Kunzelmann K, Ohrui T, Chin L, Eng K, Finkbeiner WE, Widdicombe JH, Gruenert DC: CFTR expression and chloride secretion in polarized immortal human bronchial epithelial cells. Am J Respir Cell Mol Biol 1994;10:38-47.

27 Livak KJ, Schmittgen TD: Analysis of relative gene expression data using real-time quantitative PCR and the 2(-delta delta $\mathrm{C}(\mathrm{T})$ ) method. Methods 2001;25:402-408.

28 Di Stefano A, Caramori G, Barczyk A, Vicari C, Brun P, Zanini A, Cappello F, Garofano E, Padovani A, Contoli M, Casolari P, Durham AL, Chung KF, Barnes PJ, Papi A, Adcock I, Balbi B: Innate immunity but not NLRP3 inflammasome activation correlates with severity of stable COPD. Thorax 2014;69:516-524.

29 Cakebread JA, Haitchi HM, Xu Y, Holgate ST, Roberts G, Davies DE: Rhinovirus-16 induced release of IP-10 and IL- 8 is augmented by Th2 cytokines in a pediatric bronchial epithelial cell model. PLoS One 2014;9:e94010.

30 Roos-Engstrand E, Wallin A, Bucht A, Pourazar J, Sandström T, Blomberg A: Increased expression of p38 MAPK in human bronchial epithelium after lipopolysaccharide exposure. Eur Respir J 2005;25:797-803.

-31 Bezzerri V, Borgatti M, Finotti A, Tamanini A, Gambari R, Cabrini G: Mapping the transcriptional machinery of the IL-8 gene in human bronchial epithelial cells. J Immunol 2011;187:6069-6081.
32 Yang JJ, Wang DD, Sun TY: Flagellin of Pseudomonas aeruginosa induces transforming growth factor beta 1 expression in normal bronchial epithelial cells through mitogen activated protein kinase cascades. Chin Med J (Engl) 2011;124:599-605.

33 Zhang JX, Xu WJ, Han YP, Bai C, Li Q: Effects on chemotactic factor expression in bronchial epithelial cells by co-stimulation of poly(I:C) and lipopolysaccharide and the underlying mechanism (in Chinese). Xi Bao Yu Fen Zi Mian Yi Xue Za Zhi 2012;28:10461050.

34 Durham AL, McLaren A, Hayes BP, Caramori G, Clayton CL, Barnes PJ, Chung KF, Adcock IM: Regulation of Wnt4 in chronic obstructive pulmonary disease. FASEB J 2013; 27:2367-2381.

35 Heijink IH, de Bruin HG, van den Berge M, Bennink LJ, Brandenburg SM, Gosens R, van Oosterhout AJ, Postma DS: Role of aberrant WNT signalling in the airway epithelial response to cigarette smoke in chronic obstructive pulmonary disease. Thorax 2013;68:709716.

36 Heijink I, van Oosterhout A, Kliphuis N, Jonker M, Hoffmann R, Telenga E, Klooster $\mathrm{K}$, Slebos DJ, ten Hacken N, Postma D, van den Berge M: Oxidant-induced corticosteroid unresponsiveness in human bronchial epithelial cells. Thorax 2014;69:5-13.

37 Sohn MH, Lee KE, Kim KW, Kim ES, Park JY, Kim KE: Calcium-calmodulin mediates house dust mite-induced ERK activation and IL-8 production in human respiratory epithelial cells. Respiration 2007;74:447-453.

38 MacNee W, Allan RJ, Jones I, De Salvo MC Tan LF: Efficacy and safety of the oral p38 inhibitor PH-797804 in chronic obstructive pulmonary disease: a randomised clinical trial. Thorax 2013;68:738-745.

39 Di Stefano A, Caramori G, Ricciardolo FL, Capelli A, Adcock IM, Donner CF: Cellular and molecular mechanisms in chronic obstructive pulmonary disease: an overview. Clin Exp Allergy 2004;34:1156-1167. 